\title{
Extracts from Southern Theory: The global dynamics of knowledge in social science
}

\author{
Raewyn Connell
}

\section{From Chapter 1: Empire and the creation of a social science}

\section{Origin stories}

Open any introductory sociology textbook and you will probably find, in the first few pages, a discussion of founding fathers focused on Marx, Durkheim and Weber. The first chapter may also cite Comte, Spencer, Tönnies and Simmel, and perhaps a few others. In the view normally presented to students, these men created sociology in response to dramatic changes in European society: the Industrial Revolution, class conflict, secularisation, alienation and the modern state. This curriculum is backed by histories such as Alan Swingewood's (2000) Short History of Sociological Thought. This well-regarded British text presents a two-part narrative of 'Foundations: Classical Sociology' (centring on Durkheim, Weber and Marx), and 'Modern Sociology', tied together by the belief that 'Marx, Weber and Durkheim have remained at the core of modern sociology' (2000: x). Sociologists take this account of their origins seriously. Twenty years ago, a star-studded review of Social Theory Today began with a ringing declaration of 'the centrality of the classics' (Alexander 1987). In the new century, commentary on classical texts remains a significant genre of theoretical writing (Baehr 2002).

The idea of classical theory embodies a canon, in the sense of literary theory: a privileged set of texts, whose interpretation and reinterpretation defines a field (Seidman 1994). This particular canon embeds an internalist doctrine of sociology's history as a social science. The story consists of a foundational moment arising from the internal transformation of European society; classic discipline-defining texts written by a small group of brilliant authors; and a direct line of descent from them to us.

But sociologists in the classical period itself did not have this origin story. When Franklin Giddings (1896), the first professor of sociology at Columbia University, published The Principles of Sociology, he named as the founding father-Adam Smith. Victor Branford (1904), expounding 'the founders of sociology' to a meeting in London, named as the central figure - Condorcet. 
Turn-of-the-century sociology had no list of classic texts in the modern sense. Writers expounding the new science would commonly refer to Comte as the inventor of the term, to Darwin as the key figure in the theory of evolution, and then to any of a wide range of figures in the landscape of evolutionary speculation. Witness the account of the discipline in the second edition of Dynamic Sociology (1897) by Lester Ward, later the founding president of the American Sociological Society. At the time of the first edition in 1883, Ward observed, the term 'sociology' had not been in popular use. However, in the intervening decade a series of brilliant scientific contributions had established sociology as a popular concept. There were now research journals, university courses, societies; and sociology 'bids fair to become the leading science of the twentieth century, as biology has been that of the nineteenth'. Ward listed 37 notable contributors to the new science. The list included Durkheim and Tönnies, but not Marx or Weber.

The list of notables became a common feature in the textbooks of sociology that multiplied in the United States from the 1890s, Giddings' Principles being one of the first. (Ward had included Giddings in his list, and Giddings politely included Ward in his.) The famous 'Green Bible' of the Chicago School, Park and Burgess's (1924) Introduction to the Science of Sociology, listed 23 'representative works in systematic sociology'. Simmel and Durkheim were among them, but not Marx, Weber or Pareto. Only one work by Weber was mentioned in this thousand-page volume, and then only in the notes.

As late as the 1920s, then, there was no sense that certain texts were discipline-defining classics demanding special study. Rather, there was a sense of a broad, almost impersonal advance of scientific knowledge, the notables being simply leading members of the pioneering crew. Sociologists accepted the view, articulated early in the history of the discipline by Charles Letourneau (1881: vi), who was to hold the first chair of sociology in the world, that: 'The commencement of any science, however simple, is always a collective work. It requires the constant labour of many patient workmen . . .'

We therefore have strong reasons to doubt the conventional picture of the creation of sociology. This is not just to question the influence of certain individuals. We must examine the history of sociology as a collective product - the shared concerns, assumptions and practices making up the discipline at various times, and the shape given that history by the changing social forces that constructed the new science.

\section{Global difference and empire}

Sociology as a teaching discipline and a public discourse was constructed during the final two decades of the nineteenth century and the first decade of the twentieth in the great cities and university towns of France, the United States, 
Britain, Germany and, a little later, Russia. The internalist foundation story interprets these places as the site of a process of modernisation, or capitalist industrialisation, with sociology seen as an attempt to interpret what was emerging here. 'It was above all a science of the new industrial society' (Bottomore 1987: 7).

The main difficulty with this view is that it does not square with the most relevant evidence - what sociologists at the time were writing. Most general textbooks of sociology, up to World War I, did not have a great deal to say about the modernisation of the society in which the authors lived. Giddings' Readings in Descriptive and Historical Sociology (1906), typical in this respect, ranged from polyandry in Ceylon via matrilineal survivals among the Tartars to the mining camps of California. It was so little focused on modernity that it took as its reading on 'sovereignty' a medieval rendering of the legend of King Arthur.

What is in college textbooks need not correspond to the research focus of sociology, but on this too we have abundant evidence. Between 1898 and 1913, Émile Durkheim and his hard-working collaborators produced twelve issues of L'année sociologique, an extraordinarily detailed international survey of each year's publications in, or relevant to, sociology. In these 12 issues, nearly 2400 reviews were published. (I have counted only the reviews in large type, whatever their length, not the brief notices in small type in the early issues, nor the listings of titles without reviews.) The reviews concerning Western/Northern Europe and modern North America increase with time: they average 24 per cent of all reviews in the first six issues, 28 per cent in the next five issues, and 32 per cent in the bumper issue of the year before the war.

Modern industrial society was certainly included: the journal published reviews about the American worker, the European middle class, technology in German industries, books by the Webbs and by Sombart, Booth on London poverty, even a work by Ramsay MacDonald, later Labour prime minister of Britain. But works focused on the recent or contemporary societies of Europe and North America made up only a fraction of the content of L'année sociologique: about 28 per cent of all reviews. Even fewer were focused on 'the new industrial society', since the reviews on Europe included treatises on peasant folk-tales, witchcraft in Scotland, crime in Asturias and the measurements of skulls.

Twice as many of the reviews concerned ancient and medieval societies, colonial or remote societies, or global surveys of human history. Studies of holy war in ancient Israel, Malay magic, Buddhist India, technical points of Roman law, medieval vengeance, Aboriginal kinship in central Australia and the legal systems of primitive societies were more characteristic of sociology as seen in L'année sociologique than studies of new technology or bureaucracy.

The enormous spectrum of human history that the sociologists took as their domain was organised by a central idea: difference between the civilisation of 
the metropole and other cultures whose main feature was their primitiveness. I will call this the idea of global difference. Presented in many different forms, this contrast pervades the sociology of the late nineteenth and early twentieth centuries.

The idea of global difference was often conveyed by a discussion of 'origins'. In this genre of writing, sociologists would posit an original state of society, then speculate on the process of evolution that must have led from then to now. The bulk of the three volumes of Herbert Spencer's Principles of Sociology, first issued in the 1870s, told such a story for every type of institution that Spencer could think of: domestic institutions, political institutions, ecclesiastical institutions, and so on. Spencer acted as if the proof of social evolution were not complete without an evolutionary narrative, from origins to the contemporary form, for each and every case.

The formula of development from a primitive origin to an advanced form was widespread in Victorian thought (Burrow 1966). Sociologists simply applied a logic that their audience would find familiar. The same architecture is found in works as well known as Durkheim's Division of Labour in Society (1893) and as obscure as Fairbanks' Introduction to Sociology (1896).

In none of these works was the idea of an origin taken as a concrete historical question. It could have been, because historians' knowledge of early societies was growing dramatically in these decades. Troy, Mycenae and Knossos were excavated by Schliemann and Evans. Flinders Petrie systematised the archaeology of Egypt, and the first evidence of Sumerian culture was uncovered at Lagash and Nippur (Stiebing 1993). But sociologists were not interested in where and when a particular originating event occurred, nor were they concerned about when the major changes actually happened. Time functioned in sociological thought mainly as a sign of global difference.

Durkheim did not have to find a precise time in the past for 'segmentary societies'; they existed in his own day. Durkheim used the example of the Kabyle of Algeria as well as the ancient Hebrews, and made no conceptual distinction between the two. He knew about the Hebrews because the ancient texts were in his library. How did he know about Kabylia? Because the French had conquered Algeria earlier in the century, and at the time Durkheim wrote, French colonists were evicting the local population from the best land (Bennoune 1988). Given the recent history of conquest, peasant rebellion and debate over colonisation, no French intellectual could fail to know something about the Kabyle. Indeed, the social life of France's North African subjects was being documented in great detail by a series of private and official enquiries (Burke 1980).

Algeria was not an isolated case. In the dozen years before Division of Labour was published, the armies of the French republic had moved out from Algeria 
to conquer Tunisia; had fought a war in Indo-China, conquered Annam and Tonkin (modern Vietnam) and seized control of Laos and Cambodia; and had established a protectorate over Madagascar. Under the Berlin Treaty of 1885 , French trading posts in Central and Western Africa became the basis of a whole new empire. While Durkheim was writing and publishing the Division of Labor and the Rules of Sociological Method (1895), French colonial armies were engaged in a spectacular series of campaigns against the Muslim regimes of inland North and West Africa which produced vast conquests from the Atlantic almost to the Nile.

All this was part of a larger process. The British empire, also a maritime empire with a pre-industrial history, similarly gained a new dynamism and grew to a vast size in the nineteenth century (Cain and Hopkins 1993). The thirteen-colony United States became one of the most dynamic imperial powers of the nineteenth century, with about 80 years of overland conquest and settlement (the 'westward expansion'), followed by a shorter period of overseas conquest. The Tsarist overland conquests, begun in earlier centuries, were extended to North-east and Central Asia. In the later part of the nineteenth century, they were consolidated by Russian settlement. Prussia's expansion as an imperial power began with conquest within Europe - in the process, setting up a relationship between dominant and conquered races in the East which became the subject of young Max Weber's (1894) first sociological research. German overseas colonies in Africa and the Pacific followed the formation of the Reich in 1871. By the time the system of rival empires reached its crisis in the Great War of 1914-18, the expansion of Western power to a global scale had reached its climax.

In this light, the making of sociology takes on a new significance. The places where the discipline was created were the urban and cultural centres of the major imperial powers at the high tide of modern imperialism. They were the 'metropole', in the useful French term, to the larger colonial world. The intellectuals who created sociology were very much aware of this.

Since Kiernan's (1969) remarkable survey The Lords of Human Kind, historians have begun to grasp the immense impact that the global expansion of North Atlantic power had on popular culture (MacDonald 1994) and intellectual life (Said 1993) in the metropole, as well as in the colonies. It would be astonishing if the new science of society had escaped the impact of the greatest social change in the world at the time. In fact, the relationship was intimate. Sociology was formed within the culture of imperialism, and embodied an intellectual response to the colonised world. This fact is crucial in understanding the content and method of sociology, as well as the discipline's wider cultural significance. 


\section{Chapter 4: The Discovery of Australia}

Australia is an English colony. Its cultural pattern is based on that fact of history - or, more precisely, on that pair of facts. Direct English inheritance determines the general design of our living and its detail, ranging from our enthusiasm for cricket to our indifference to the admirable wines which we produce. But the fact of our colonialism has a pervasive psychological effect, setting up a relationship as intimate and uneasy as that between an adolescent and his parent.

-A. A. Phillips (1953)

Two centuries ago, having lost thirteen colonies in North America, the British state planted a new one, a penal settlement, as far away as it was possible to sail. Both the memoirs of officials and surviving narratives from the convicts reveal how strange the new environment was felt to be: birds that laughed instead of singing, animals that hopped instead of running, Christmas in summer, and a native population for whom no place could be found in the European social order.

A ruthless expansion into this alien world followed, and through the nineteenth century fortunes were made in pastoralism, mining and trade. Wool, gold, wheat, meat and silver were shipped out to Europe (and more recently, coal and iron ore to East Asia). For a couple of generations, import-substitution industrialisation planted factories in the cities and manufacturers became prominent in the local ruling class; a witty economist wrote a book calling Australia 'a small rich industrial country' (Arndt 1968). Rich it remains, but it is now deindustrialised: the twenty-first century economy centres on services and mining. Under the 'White Australia' policy, official until the 1960s, a workforce was imported from Europe while immigration from Asia was forbidden. Diversity has grown but the large majority are still of European descent. Politicians still proclaim Australia's affiliation with the metropole: formerly with the British Empire, now with Western civilisation and the American Alliance.

This history produced cultural dilemmas that are bitterly contested. A small European community parked on the edge of Asia harbours racial anxieties which are still capable of turning elections. The relation between settler and Indigenous people has become an inflamed, unresolved issue (see Chapter 9). Identification with the metropole plus geographical remoteness plus economic dependence have led to chronic difficulties about identity. The prevailing attitude, which the literary critic A.A. Phillips famously dubbed 'the cultural cringe', is contested by outbursts of nationalism and searches for local grounding that have inspired some of the best Australian literature and art. But Australian nationalism, once socially radical, has gradually been captured by the political right-itself committed to dependence on metropolitan power and international capitalism. 
In this contradictory world of settler colonialism, what happens to the social sciences? The relationship between colony and metropole remains crucial, and the broader cultural problems are reflected within social science disciplines. But the shape of these problems changes. In this chapter, I focus again on the case of sociology, and analyse colony-metropole relations in two historical moments: the Australian colonies' role in the making of sociology in the second half of the nineteenth century; and the forming of an academic discipline of sociology in Australian universities from the 1950s to the 1970s. Recent years have produced other possibilities, which I consider at the end of the chapter.

\section{Australia's place in the making of sociology}

During the second half of the nineteenth century, metropolitan texts - especially the writings of Comte and Spencer - circulated far beyond the metropole. Spencer had a considerable impact in Japan and India; Comte was read in Iran and had a powerful influence in Brazil. Such an impact depended on the existence of a local intelligentsia prepared to work with these ideas. The creation of a higher education system in Australia exactly coincided with the invention of sociology in the metropole. Comte's System of Positive Polity, subtitled Treatise of Sociology, was published between 1851 and 1854 in the early days of Louis Bonaparte's regime, the subject of Marx's Eighteenth Brumaire; the University of Sydney opened for business in 1852 and the University of Melbourne very soon after.

The colonial universities' curriculum was originally a stodgy amalgam of classics and technical training, but it gradually broadened, and as it did so it was possible for themes from 'the social science' to be included. Colonial newspapers - more diverse and intellectually substantial then than now-provided another arena in which 'the social question', relations between races, the status of women and other sociological themes were debated.

In the second half of the nineteenth century, these debates developed actively in Melbourne, then one of the largest cities in the world of settler colonialism, with a diverse and radical intelligentsia and a surprisingly open-minded university. A notable product of this milieu was the work of W.E. Hearn, an Irish classicist who became professor at the University of Melbourne in the 1850s and produced an impressive series of books over the next 30 years (La Nauze 1949). The unstructured state of the social sciences at the time is illustrated by the fact that Hearn was professor of history, literature, logic, political economy and law-most of them at the same time. His book Plutology, published in Melbourne in 1863, was arguably the first important text of economics to be written in Australia, and The Aryan Household, published in 1878, was the first important text of sociology.

The Aryan Household is recognisably part of the genre of studies of social progress, in broad comparative style, that were undertaken in the 1870 s and 1880s by 
Tylor and Spencer in Britain, Letourneau in France, Ward in the United States and Tönnies in Germany. Hearn explained his purpose clearly in the introduction:

I propose to describe the rise and the progress of the principal institutions that are common to the nations of the Aryan race. I shall endeavour to illustrate the social organization under which our remote forefathers lived. I shall, so far as I am able, trace the modes of thought and of feeling which, in their mutual relations, influenced their conduct. I shall indicate the germs of those institutions which have now attained so high a development; and I shall attempt to show the circumstances in which political society took its rise, and the steps by which, in Western Europe, it supplanted its ancient rival. (Hearn 1878: 2)

Several things are interesting about this passage. The tone is sober-this is intended as a technical contribution to science, not a popularisation. Hearn makes a simple identification with Europeans ('our remote forefathers'), reflecting the idea of Australian colonists as transplanted Britons. There is a clear presupposition of progress ('so high a development'). Notable also is Hearn's opening of a contrast between two types of society. This is an early example of the technique of grand ethnography (Chapter 1), which soon became central to metropolitan sociologists' representations of time and progress. A few pages later, Hearn gives a very clear summary of this way of representing change:

In all its leading characteristics-political, legal, religious, economic - archaic society presents a complete contrast to that in which we live...no central government... no national church ... few contracts... Men lived according to their customs... They were protected, or, if need were, avenged, by the help of their kinsmen. There was, in short, neither individual nor State. The clan, or some association founded upon the model of the clan, and its subdivisions, filled the whole of our forefathers' social life (Hearn 1878: 4-5).

The rest of the book fills out this contrast. It traverses a range of sociological themes: the nature of custom, the position of women, the social organisation of the household, types of association, types of power, and the relationship between the state and civil society. But there is one oddity. Hearn, although he lived in a colony, found his examples rigorously in the early history of the 'Aryan' nations of Europe and their supposed ancestors.

It may partly be for that reason that Hearn's brilliant beginning found few Australian followers; he created no local school of sociological research. His text was, rather, a contribution from the colonies to the metropolitan literature of speculation about social progress. There was no institutionalisation of 'sociology' in the colonial universities, any more than there was at Oxford or Cambridge. When in the 1880s the University of Sydney began to modernise its badly 
outdated Arts curriculum, it developed modern history, philosophy and political economy, but did not try to develop sociology (Turney, Bygott and Chippendale 1991: $271 \mathrm{ff}$.).

That development occurred shortly afterwards in North American universities. The explosion of undergraduate sociology courses, textbooks, professional organisations and research output in American colleges met with an upsurge of interest in sociology across the North Atlantic, including the first chair of sociology in Britain in 1907.

It was these events that Francis Anderson, appointed to a chair of philosophy during the University of Sydney renovation of Arts, had in mind when he delivered the 1911 lecture that is often taken as the starting point of Australian sociology. Sociology in Australia: A Plea for its Teaching, published the next year as an eleven-page pamphlet, was not a work of sociology, nor was Anderson in any sense a sociologist. He was a professional philosopher who held a Comtean view of the structure of science. In this view, sociology was the 'mother science' that stated the broad principles of which specific sciences such as economics were examples. Sociology's task was 'to ascertain the natural laws which are manifested in social growth' (Anderson 1912: 10). Anderson seized upon the recent expansion of economics and commerce teaching at the University of Sydney to argue that the mother science should also be taught.

Anderson's view of sociology was, in 1912, already a little dated. Within ten years, the whole system of evolutionary social science and its laws of progress would be plunged into terminal crisis. Nothing like Anderson's program could possibly be implemented. His lecture marks the end of an era rather than the beginning: Comtean theory never got established here. But there was another feature of colonial reality that did make Australia important for sociology in the nineteenth century.

As I showed in Chapter 1, reports from the colonised world became a major data source for evolutionary social science. In the preface to his great work Primitive Culture, Edward Tylor (1873) made a 'general acknowledgment of obligations to writers on ethnography and kindred sciences, as well as to historians, travellers, and missionaries' (1873: I, vi). Such observers provided sociologists with rich documentation of the primitive which their grand ethnography sought to contrast with the advanced society of the metropole.

The British conquest of Australia was no exception. The first colonial governor was instructed to make contact with the natives and take them under his protection, which he dutifully attempted to do. His reports launched British colonial administration on a see-saw of conciliation, coercion and hand-wringing over the growing frontier violence between settlers and Aborigines. This lasted until the white colonists had seized the richest land in eastern Australia and persuaded Whitehall to grant them control of the rest, in the form of responsible 
government - in other words, quasi-independence. Accounts of this process, with descriptions of the Aboriginal communities to whom it was applied, flowed back to Britain.

A notable example comes from one of the great scientific documents of the age. Charles Darwin's Journal of Researches (better known as The Voyage of the Beagle) contains a chapter about his visit to Sydney and trip over the Blue Mountains, and then short visits to Van Diemen's Land (now Tasmania) and King George's Sound (now Western Australia). Here he witnessed a 'corrobery' of the White Cockatoo people. His description ends:

When both tribes mingled in the dance, the ground trembled with the heaviness of their steps, and the air resounded with their wild cries. Every one appeared in high spirits, and the group of nearly naked figures, viewed by the light of the blazing fires, all moving in hideous harmony, formed a perfect display of a festival amongst the lowest barbarians (Darwin 1839: 426).

Despite the pejoratives, Darwin was not hostile to the Australian Aboriginal groups he met. He admired their bushcraft and hunting skills, sympathised with their vulnerability to imported diseases, and did not blame them for the frontier violence. But he did regard the Australian Aborigines as a more primitive people than the British; he expected their extinction, and he saw this as an unavoidable consequence of a stronger variety of man meeting a weaker: 'Wherever the European has trod, death seems to pursue the aboriginal' (Darwin 1839: 411).

Hundreds of such accounts of native life in Australia - some much more substantial than Darwin's - came back to the metropole and became part of the raw material from which evolutionary social science was built. I could give examples from very well-known writers including Tylor himself and William Graham Sumner, but will quote just one, the progressive liberal Lester Ward. Surveying the races of mankind in his Dynamic Sociology, Ward (1897) declared:

Among other very low savage races may be mentioned the Fuegians, who, though of rather large stature, are mentally little superior to animals; the aboriginal Australians of the interior, who, along with other simian characteristics, are nearly destitute of the fleshy muscles constituting the calf of the leg (gastrocnemius and soleus) . . . Many of these tribes and races live almost entirely after the manner of wild beasts, having nothing that can be called government, religion, or society (1897: II, 418).

None of these theorists had visited Australia or met an Australian Aboriginal person, and none made any attempt to verify their startling (and, in Ward's and Sumner's cases, undoubtedly false) claims. Australian Aborigines had no human reality for them. They were simply tokens in the construction of a scientific fantasy of the primitive, which in turn validated a doctrine of social evolution. 
Australia's role in the making of sociology, like that of the rest of the colonised world, was to be a data mine, a source of ethnographic examples of the primitive. Within the colonised world, Australia had the distinction of being the most primitive of all, illustrating the extremity of degradation or backwardness.

This was certainly the assumption behind the most famous appearance of Australia in the texts of 'classical' sociology. In the last decades of the nineteenth century, deliberate ethnographic observation was replacing 'historians, travellers and missionaries' as the key source of information about non-European peoples in the intellectual shift that produced modern social anthropology. Some of this pioneering work was done in Australia, and among the most influential was research conducted in the 1890s, in the central desert around Alice Springs, by Baldwin Spencer and F.J. Gillen.

Back in Paris, Spencer and Gillen's well-illustrated report The Native Tribes of Central Australia was read with enthusiasm by Durkheim and his colleagues. It was warmly reviewed in L'année sociologique, and a decade later became the main empirical basis for Durkheim's last book, The Elementary Forms of Religious Life, published in 1912.

In this book, the customs and mythology of the Arrernte people as they stood in the late nineteenth century became the basis for a general sociology of religion. Durkheim, like most sociologists who wrote about 'Australians', understood little of the diversity or dynamism of Indigenous cultures in Australia. Durkheim knew there were different communities, but believed they were 'perfectly homogeneous' because their societies 'all belong to one common type' (Durkheim 1912: 95). The Arrernte were used for one reason. Durkheim thought he had found, in Spencer and Gillen's ethnography, a detailed description of the most primitive form of religion, and he thought that by studying the most primitive form, he could reveal the most fundamental truths about religion. There is no ambiguity about this. Durkheim says exactly:

In this book we propose to study the most primitive and simple religion which is actually known ... A religious system may be said to be the most primitive ... in the first place when it is found in a society whose organization is surpassed by no others in simplicity; and secondly when it is possible to explain it without making use of any element borrowed from a previous religion (Durkheim 1912: 1).

'Australian totemism' fitted the bill, because Australian Aborigines had the most primitive documented society. Here the crude racism of a Ward or Sumner is transcended - up to a point. Durkheim's prejudice takes a very sophisticated form; his sociology embeds a deeply ethnocentric viewpoint nonetheless. And it conceals a radical misunderstanding of Australian Indigenous cultures. 
This was already knowable in Durkheim's day. In a biting review of The Elementary Forms published the following year, the anthropologist van Gennep (celebrated for his work on 'rites of passage') pointed out that the book was riddled with doubtful factual claims. But, more importantly, it was based on a monumental conceptual error - an error, I would say, that infected the whole enterprise of evolutionary sociology:

The idea he [Durkheim] has derived from them [the ethnographic documents] of a primitive man ... and of 'simple' societies is entirely erroneous. The more one knows of the Australians and the less one identifies the stage of their material civilization with that of their social organization, one discovers that the Australian societies are very complex, very far from the simple and the primitive, but very far advanced along their own paths of development (Van Gennep in 1913, quoted in Lukes 1985: 525).

\section{The creation of Australian academic sociology}

In the four decades that followed Anderson's appeal and Durkheim's great fantasy, while metropolitan sociology changed profoundly (see Chapter 1), little happened organisationally in Australia. Bits of the new welfare-state sociology popped up in odd contexts - the Workers' Education Association, university philosophy courses, political speculation by progressive liberals, or surveys of educational inequalities. But there was nothing like the Chicago School, let alone an Australian Parsons, to pull them together.

Australia's most brilliant social scientist, Vere Gordon Childe, left the country in 1921, dismayed at the Labor Party's betrayal of the workers, and went off to Europe to invent scientific prehistory. For the next generation his astonishing creativity was practically ignored in Australia, where it was known that he was a communist (Gathercole, Irving and Melleuish 1995). Other talented social researchers also left the country, such as Elton Mayo who became a founder of industrial sociology in the United States.

When research programs within the new sociological episteme finally appeared in Australia, they were outgrowths from social anthropology and social psychology. The professor of anthropology at the University of Sydney, A.P. Elkin, famous for his work on Aboriginal cultures, began in the early 1940s to direct some of his students towards ethnographic studies of 'our own society' - that is, white settler society. He also undertook a study of wartime social integration based on survey data. The notable products of this initiative were a well-observed, though modestly presented, ethnography of a mining town by Alan Walker (1945), and an even better ethnography of rural kinship and family life by Jean Craig (1957), later known to every sociologist in Australia as Jean Martin. 
In the late 1940s, the new professor of psychology at the University of Melbourne, Oscar Oeser, launched a research program on 'social behaviour' which also drifted into the territory of the new sociology. His research team conducted elaborate observational and interview studies in a Victorian country town, in suburbs of Melbourne, and in seven factories. The topics included class-consciousness, job satisfaction, industrial relations and family life. This style of social-realist field observation was soon dropped by Australian psychology, which fell under the spell of behaviourism. But the three volumes of the Social Structure and Personality series (Oeser and Hammond 1954; Oeser and Emery 1954; Lafitte 1958) provided key empirical material for the first university courses in sociology, which were launched almost immediately after these books were published.

During the 1950s, the idea of social surveys on the white community became familiar. An Australian market research firm, Roy Morgan Research, started sample surveys using its 'Gallup Poll' in the 1940s. The poll findings, presented by Morgan as scientific measures of opinion, were reported in the press and increasingly noticed by politicians. University- and welfare-based surveys appeared, describing specific social groups and their problems. They included the aged in Victoria, surveyed by a University of Melbourne group (Hutchinson 1954); the young in Sydney, surveyed by a University of Sydney group (Connell, Francis and Skilbeck 1957); and the leisure problems of a Melbourne suburban estate, surveyed by the Brotherhood of St Laurence (Scott and U'ren 1962). Academic researchers also began to see the national census as a source of data for social analysis. George Zubrzycki (1960) thus conducted 'a demographic survey' of immigrants in Australia.

This generation of social researchers forged a new relationship with metropolitan sociology. Australia ceased to be a data mine, an economy exporting facts (or imagined facts). Most of these studies were published in Australia and remained unknown in the metropole. However, the new generation of researchers adopted the new American definition of the subject-matter of sociology, and they adopted the methods of metropolitan researchers.

Walker's Coaltown, for instance, mentioned no theory and did not compare its findings with any other research. But it was clearly modelled on community studies such as the Lynds' Middletown and Warner's 'Yankee City' series. The Sydney educationists' Growing Up in an Australian City was more explicitly connected with models in the American sociology of youth. For Old People in a Modern Australian Community, the academic and business sponsors actually imported from Britain 'an experienced investigator of social problems' to run the study (Hutchinson 1954: v).

This stance was familiar in Australian intellectual life at the time. A.A. Phillips (1953: 85) diagnosed 'the persistence of the colonial surrender in the Australian 
mind' as a major problem for literature too. So it was easy for Australian sociology to constitute itself as a branch office of metropolitan sociology, importing metropolitan methods and topics in order to address a local audience about local versions of social problems.

The commonest title of an Australian sociological report, for the 30 years from 1950, was $X$ in Australia - where $X$ was a phenomenon already defined in the metropole and for which metropolitan paradigms of research were available. $X$ might be 'religion', 'status and prestige', 'social stratification', 'divorce', 'marriage and the family', 'urbanization', 'prostitution', 'political leadership', 'women', 'mass media', 'immigrants' or 'sociology' itself. (These are all actual titles from the period.) The task of the Australian sociologist was to apply the metropolitan research technique, demonstrate that the phenomenon also existed in Australia, and say empirically what form it took here. In some of this writing there was a faint missionary flavour, as if the sociologists were bringing new light to the unsophisticated locals.

These metropolitan-style studies of 'our own society' were the knowledge base on which an academic discipline called 'sociology' was installed in Australia's expanding university system. The action was very fast. A half-dozen years, from 1959 to 1965, saw the first named chair of sociology, the first sociology teaching programs, the first textbook, the foundation of a professional association, and the first issues of its academic journal. This brief period even saw the first pop sociology best-seller, The Lucky Country, written by a journalist (Horne 1964). In the following decade, another ten departments of sociology sprang up around the country.

But a collection of social surveys was not enough to claim space in the universities as a new discipline. There also needed to be ideas, as Davies and Encel observed in the first edition of their textbook Australian Society (1965). In a vigorously argued paper on 'The Scope and Purpose of Sociology', Harold Fallding (1962) insisted that sociology was now an established discipline in terms of its object of knowledge - systems of social action - and its theoretical logic. Since no sociological theory was being produced in Australia, this too had to be imported from the metropole. Fallding's solution was to import Parsonian functionalism in a lump. Others imported empiricism, Weberianism, interpretive sociology and, a little later, neo-Marxism.

The result was a hybrid structure of knowledge in the new discipline, where Australian sociologists combined metropolitan theory and methodology with local data and audiences. A notable example was Sol Encel's (1970) monograph Equality and Authority. Encel's book traversed the metropolitan (mainly British and US) controversies about class and stratification, adopted a modified Weberian position, and then reported seriatim the author's impressive compilations of data about Australian elites. Another example, I have to confess, was Connell and 
Irving's Class Structure in Australian History (1980). We started with a chapter debating metropolitan theories of class before settling into an exposition of Australian empirical material.

Along with metropolitan theory - though this was hardly noticed at the time - came a metropolitan vision of what society was and how we should talk about it. 'Australian society' was simply presumed to be the same kind of thing, for which the same conceptual categories were unproblematically appropriate.

The rising quality of Australian research entrenched this pattern. As Australian sociologists became more sophisticated in using the metropolitan tools, they began to publish in metropolitan journals. There were good reasons: as well as the desire to find a wider audience, the prestige attached to international publication greatly helped promotion in Australian universities. However, to publish in those forums, Australians had to write in forms familiar to metropolitan editors: to use metropolitan concepts, address metropolitan literatures, and offer credible interventions in metropolitan debates. Australian sociology was thus produced as a professional account of Australian society as seen through metropolitan eyes.

The construction of Australian sociology as an academic discipline in the decades 1950-80 thus completely reversed the relationship between Australia and metropolitan sociology that had existed a hundred years earlier. Then Australia was treated as the site of difference - in fact, extreme difference-from the advanced society of the metropole. Now Australia was treated as the site of similarity.

Of course, this involved a shift of empirical interest from Aboriginal to settler society. But Australian society was not theorised in the new discipline as a settler society; it was simply regarded as part of modernity. Indigenous cultures were now regarded as the business of anthropology - which was, in Australian universities, the older and more prestigious discipline. This was a boundary the sociologists did not yet challenge. The relationship between Indigenous society and settler/modern society that had been so important for evolutionary sociology simply vanished as an intellectual theme.

Aboriginal people did concern sociologists, but in a new way: as the subjects of social processes characteristic of modernity. They could be seen as a disadvantaged group in a system of social stratification (Ancich et al. 1969). More commonly, they were classified under the North American rubric of 'ethnic minority'. This is how they were treated, for instance, in Baldock and Lally's (1974) survey of Sociology in Australia and New Zealand. In this book Aboriginal people appeared in a chapter on 'studies of ethnic minorities' whose primary focus was postwar non-British immigration. The ironic result of the new structure of sociological knowledge was that Indigenous groups were understood as being the same kind of group as the most recent settlers. 
With local sociology wholly dependent on metropolitan concepts and methods, people began to wonder about the identity puzzle. What was specifically Australian about this? Australian sociology had, perhaps, a characteristic empirical focus - for instance, on migration. Indeed, Jean Martin, George Zubrzycki and other sociologists were prominent in constructing the discourse of multiculturalism that framed Australian policy on ethnicity and immigration until the 1990s revival of racism.

Alternatively, Australian sociology had a characteristic irony, because sociologists' documentation of stratification, elites and exclusions ran counter to Australian egalitarianism. Busting 'myths' about Australia became a favoured trope in Australian sociological writing in the 1960s (e.g. Taft 1962). But it was hard to see a distinctive cultural formation in the sociological books published in Australia, or in the papers in the Australian and New Zealand Journal of Sociology. A definition of the identity of Australian sociology thus proved very elusive, even in the period when the discipline was growing most vigorously.

\section{New possibilities}

The relationship between colony and metropole has been formative for Australian sociology, though the terms of that relationship have changed. Can the terms change again?

Much of Australian sociology continues on the path already mapped out. Metropolitan theory remains hegemonic. Parsonianism and Weberianism were displaced by structuralist Marxism, and that in turn by a strong wave of post-structuralism. In the twenty-first century, Foucauldians and Bourdieuvians frolic where functionalists once safely grazed.

Theories are certainly deployed with more sophistication and skill, and it is possible for Australian sociologists to do work that is path-breaking in international terms. John Braithwaite's (1989) criminological work on reintegration comes to mind, as does Michael Pusey's Economic Rationalism in Canberra (1991). Combining survey data on federal civil servants, analysis of political and institutional change, and a social vision influenced by Habermas, Pusey created a pioneering sociology of neoliberalism which has very wide implications.

Australians have also done work in sociological theory, not as peripheral consumers of the metropole's output but as participants in metropolitan debates. Notable examples are Clare Burton's (1985) synthesis of feminism and social theory; Jack Barbalet's (1998) work on the macro-sociology of emotions; and Pauline Johnson's (2006) study of the changing idea of the public realm in the thought of Jürgen Habermas. This work is often published in the metropole and, whether or not it uses any Australian research or experience, the focus is on a metropolitan literature. In effect, these authors have followed the same 
strategy as W.E. Hearn, doing Northern theory in new conditions and abandoning the identity problem.

But in a changed cultural and political environment, an opposite strategy was also possible: focusing on the specificity of Australia as a product of settler colonialism. Interest in the relationship between indigenous and settler society was revived by historians of frontier conflict, by anthropologists' rethinking of their own connection with colonialism, and above all by the Aboriginal Land Rights movement (see Chapter 9). A sociologist such as Vivien Johnson (1996) could become deeply interested in the Aboriginal art movement, considering not only the body of artistic work but also the ways in which it is appropriated by the dominant culture - including widespread commercial exploitation and copyright violation. In her Radio Birdman, Johnson (1990) turned the intellectual relationships around, using some Aboriginal social concepts for analysing that most metropolitan of social phenomena: a new wave rock band.

It was also now possible to think, from an Australian starting point, about global structures and connections. This was done by Chilla Bulbeck in One World Women's Movement (1988), written before globalisation had become a popular sociological theme. This book took up the problems raised by the United Nations Decade for Women (1975-85), discussing whether it was possible to have a united international feminism, given the different situations of women in different countries, and resistance to the dominance of white Western feminism. In the sequel Re-orienting Western Feminisms (1998), Bulbeck looked more deeply at the problems of universalism and cultural difference, and offered a complex relativism as a basis for political cooperation among women's movements. Few have gone as far down this track as Bulbeck. Nevertheless, in the 1990s it became more common for Australian sociologists to set their analyses in a broader international context, or within a wider understanding of colonialism (e.g. Bottomley (1992) on migration and culture; Gilding (1997) on the family; Connell (1993) on gender).

None of this defines a distinctive Australian school of sociology. What it does mean is that Australian sociologists have recognised a wider spectrum of possibilities inherent in the geopolitical situation of a rich peripheral country and the history of settler colonialism. Recognising these possibilities, Australian sociology may contribute to much more important goals than the creation of a local ethos. For the first time, as Bulbeck's work clearly shows, it is possible to move beyond the traditional link with the metropole to link with the intellectual projects of other regions of the periphery.

Extracts (pp. 4-9 and pp. 71-86) from Southern Theory: The global dynamics of knowledge in social science by Raewyn Connell. Published by Allen \& Unwin, 2007 (ISBN 9781741753578). Copyright Raewyn Connell, 2007. 
Raewyn Connell is University Professor at the University of Sydney. A leading Australian social scientist, her work is well known in sociology, education, gender studies and political science, and has been translated into thirteen languages. Her books include Masculinities, Schools and Social Justice, Gender and Power and Making the Difference.

\section{Works cited}

Alexander, Jeffrey C. 1987. 'The centrality of the classics'. In Anthony Giddens and Jonathan H. Turner, eds, Social Theory Today. Cambridge: Polity Press, 11-57.

Ancich, M., Connell, R.W., Fisher, J.A. and Kolff, M. 1969. 'A descriptive bibliography of published research and writing on social stratification in Australia, 1946-1967'. Australian and New Zealand Journal of Sociology, vol. 5 no. 1, 48-76; vol. 5 no. 2, 128-52.

Anderson, Francis 1912. Sociology in Australia: A Plea for its Teaching. Sydney: Angus \& Robertson.

Arndt, H.W. 1968. A Small Rich Industrial Country. Melbourne: Cheshire.

Baehr, Peter 2002. Founders, Classics, Canons: Modern Disputes over the Origins and Appraisal of Sociology's Heritage. New Brunswick: Transaction.

Baldock, Cora V. and Lally, Jim 1974. Sociology in Australia and New Zealand: Theory and Methods. Contributions in Sociology, No. 16. Westport, CN: Greenwood Press.

Barbalet, J.M. 1998. Emotion, Social Theory, and Social Structure: A Macrosociological Approach. Cambridge: Cambridge University Press.

Bennoune, Mahfoud 1988. The Making of Contemporary Algeria, 1830-1987. Cambridge: Cambridge University Press.

Bottomley, Gillian 1992. From Another Place: Migration and the Politics of Culture. Melbourne: Cambridge University Press.

Bottomore, Tom 1987. Sociology: A Guide to Problems and Literature, 3rd edn. London: Allen \& Unwin.

Braithwaite, John 1989. Crime, Shame and Reintegration. Cambridge: Cambridge University Press.

Bulbeck, Chilla 1988. One World Women's Movement. London: Pluto Press.

- 1998. Re-Orienting Western Feminisms: Women's Diversity in a Postcolonial World. Cambridge: Cambridge University Press. 
Burke, Edmund, III 1980. 'The French tradition of the sociology of Islam'. In Malcolm Kerr, ed., Islamic Studies. Santa Monica, CA: Undena University Press, 73-88.

Burrow, J.W. 1966. Evolution and Society: A Study in Victorian Social Theory. Cambridge: Cambridge University Press.

Burton, Clare 1985. Subordination: Feminism and Social Theory. Sydney: George Allen \& Unwin.

Cain, P.J. and Hopkins, A.G. 1993. British Imperialism: Innovation and Expansion, 1688-1914. New York: Longman.

Connell, Raewyn 1993. 'The big picture: Masculinities in recent world history'. Theory and Society, vol. 22, 597-623.

- and Irving, T.H. 1980. Class Structure in Australian History. Melbourne: Longman Cheshire.

Connell, W.F., Francis, E.P. and Skilbeck, E.E. 1957. Growing Up in an Australian City. Melbourne: Australian Council for Educational Research.

Craig, Jean I. 1957. 'Marriage, the family and class'. In A.P. Elkin, ed., Marriage and the Family in Australia. Sydney: Angus \& Robertson, 24-53.

Darwin, Charles n.d. [1839]. Journal of Researches into the Natural History and Geology of the Countries Visited during the Voyage of H.M.S. 'Beagle' Round the World. London: Ward, Lock \& Co.

Davies, Alan and Encel, Sol, eds 1965. Australian Society. Melbourne: Cheshire.

Durkheim, Émile 1964 [1893]. The Division of Labor in Society. New York: Free Press.

— 1964 [1895]. The Rules of Sociological Method. Glencoe IL: The Free Press.

— 1976 [1912]. The Elementary Forms of the Religious Life. London: Allen \& Unwin.

—, ed. 1898-1913. L'Année sociologique, Vols 1-12. Paris: Alcan.

Encel, S. 1970. Equality and Authority: A Study of Class, Status and Power in Australia. Sydney: Cheshire.

Fairbanks, Arthur 1901 [1896]. Introduction to Sociology, 7th edn. New York: Scribner.

Fallding, Harold 1962. 'The scope and purpose of sociology'. Australian Journal of Politics and History, no. 8, 78-92.

Gathercole, Peter, Irving, T.H. and Melleuish, Gregory, eds 1995. Childe and Australia: Archaeology, Politics and Ideas. Brisbane: University of Queensland Press. 
Giddings, Franklin Henry 1896. The Principles of Sociology. New York: Macmillan.

- 1906. Readings in Descriptive and Historical Sociology. New York: Macmillan.Branford, Victor 1904. 'The founders of sociology'. American Journal of Sociology, vol. 10 no. 1, 94-126.

Gilding, Michael 1997. Australian Families: A Comparative Perspective. Melbourne: Longman.

Hearn, William Edward 1878. The Aryan Household, Its Structure and its Development. Melbourne: George Robertson.

Horne, Donald 1964. The Lucky Country: Australia in the Sixties. Ringwood: Penguin.

Hutchinson, Bertram 1954. Old People in a Modern Australian Community: A Social Survey. Melbourne: Melbourne University Press.

Johnson, Pauline 2006. Habermas: Rescuing the Public Sphere. London: Routledge.

Johnson, Vivien 1990. Radio Birdman. Melbourne: Sheldon Booth.

- 1996. Copyrites: Aboriginal Art in the Age of Reproductive Technologies. Sydney: National Indigenous Arts Advocacy Association and Macquarie University.

Kiernan, V.G. 1969. The Lords of Human Kind: Black Man, Yellow Man, and White Man in an Age of Empire. Boston: Little, Brown.

La Nauze, J.A. 1949. Political Economy in Australia: Historical Studies. Melbourne: Melbourne University Press.

Lafitte, Paul 1958. Social Structure and Personality in the Factory. London: Routledge and Kegan Paul.

Letourneau, Charles 1881. Sociology, Based upon Ethnography. London: Chapman \& Hall.

Lukes, Steven 1985. Emile Durkheim, His Life and Work: A Historical and Critical Study. Stanford: Stanford University Press.

MacDonald, Robert H. 1994. The Language of Empire: Myths and Metaphors of Popular Imperialism, 1880-1918. Manchester: Manchester University Press.

Oeser, O.A. and Emery, F.E. 1954. Social Structure and Personality in a Rural Community. London: Routledge and Kegan Paul.

- and Hammond, S.B. 1954. Social Structure and Personality in a City. London: Routledge and Kegan Paul.

Park, Robert E. and Burgess, Ernest W. 1924 [1921]. Introduction to the Science of Sociology. Chicago: University of Chicago Press. 
Phillips, A.A. 1953. 'Australian literature'. In W.V. Aughterson, ed., Taking Stock: Aspects of Mid-Century Life in Australia. Melbourne: Cheshire, 79-96.

Pusey, Michael 1991. Economic Rationalism in Canberra: A Nation-Building State Changes its Mind. London: Cambridge University Press.

Said, Edward W. 1993. Culture and Imperialism. New York: Vintage.

Scott, David and U'Ren, Robert 1962. Leisure: A Social Enquiry into Leisure Activities and Needs in an Australian Housing Estate. Melbourne: Cheshire.

Seidman, Steven 1994. Contested Knowledge: Social Theory in the Postmodern Era. Cambridge, MA: Blackwell.

Spencer, Baldwin and Gillen, F.J. 1899. The Native Tribes of Central Australia. London: Macmillan.

Stiebing, William H. 1993. Uncovering the Past: A History of Archaeology. Buffalo: Prometheus Books.

Swingewood, Alan 2000. A Short History of Sociological Thought, 3rd edn. Basingstoke: Palgrave.

Taft, Ronald 1962. 'The myth and migrants'. In P. Coleman, ed., Australian Civilization. Melbourne: Cheshire, 191-206.

Turney, Clifford, Bygott, Ursula and Chippendale, Peter 1991. Australia's First: A History of the University of Sydney Volume I, 1850-1939. Sydney: University of Sydney and Hale \& Iremonger.

Tylor, Edward B. 1873. Primitive Culture: Researches into the Development of Mythology, Philosophy, Religion, Language, Art, and Custom, 2nd edn. London: Murray.

Walker, Alan 1945. Coaltown: A Social Survey of Cessnock, NSW. Melbourne: Melbourne University Press.

Ward, Lester F. 1897. Dynamic Sociology, or Applied Social Science as Based upon Statical Sociology and the Less Complex Sciences, 2nd edn. New York: Appleton.

Weber, Max 1989 [1894]. 'Developmental tendencies in the situation of East Elbian rural labourers'. In Keith Tribe, ed., Reading Weber. London: Routledge, 158-87.

Zubrzycki, Jerzy 1960. Immigrants in Australia: A Demographic Survey Based on the 1954 Census. Melbourne: Melbourne University Press. 